\title{
DIGITAL IMAGE PROCESSING FOR EVALUATION OF PASPALUM MILLEGRANA SCHRAD ROOT SYSTEM ${ }^{1}$
}

\author{
AIRTON MARQUES DE CARVALHO ${ }^{2}$, LUIZ DIEGO VIDAL SANTOS ${ }^{3 *}$, FRANCISCO SANDRO RODRIGUES \\ HOLANDA $^{4}$, ALCEU PEDROTTI ${ }^{5}$, GUILHERME MATOS ANTONIO ${ }^{2}$
}

\begin{abstract}
The characterization of the plant root system is of great importance for the understanding of its contribution to soil shear resistance, constituting an important tool for decision making in soil bioengineering works. The objective of this work was to evaluate the growth and distribution characteristics of the root system of Paspalum millegrana Schrad. grass in Entisol using Digital Imaging Processing (DIP). The data were obtained by opening a soil pit to expose the root system of Paspalum grass up to $1.70 \mathrm{~m}$ depth. The profile wall and volumetric ring methods were used to collect quantitative information of the root system. The SAFIRA software and the ArcMAP software belonging to the ArcGIS suite were used for image processing. The profile wall method showed that Paspalum grass has a large volume of roots in the first $0.40 \mathrm{~m}$ to $1.30 \mathrm{~m}$ soil depth. It was observed that the root length and volume of Paspalum grass reach depths beyond $1.70 \mathrm{~m}$, which is important to increase soil resistance to erosion processes. The profile wall method when compared to the volumetric ring method proved to be more efficient to understand the behavior of the Paspalum grass root system since it enables an assessment of its spatial distribution with better detailing.
\end{abstract}

Keywords: Root volume. Soil bioengineering. Safira Software.

\section{PROCESSAMENTO DIGITAL DE IMAGENS PARA AVALIAÇÃO DO SISTEMA RADICULAR DO PASPALUM MILLEGRANA SCHRAD}

RESUMO - A caracterização do sistema radicular de plantas é de grande importância para a compreensão da sua contribuição na resistência ao cisalhamento do solo, constituindo uma importante ferramenta para tomada de decisão em obras de bioengenharia dos solos. Esse trabalho teve como objetivo avaliar as características de crescimento e distribuição do sistema radicular do capim Paspalum millegrana Schrad em Neossolo Quartzarênico utilizando Processamento Digital de Imagens (PDI). A obtenção dos dados foi realizada por meio de abertura de trincheira para exposição do sistema radicular do capim Paspalum até $1,70 \mathrm{~m}$ de profundidade do solo. Para a coleta de informações quantitativas do sistema radicular, foram utilizados os métodos da trincheira e anel volumétrico. Para o processamento das imagens foram utilizados os softwares SAFIRA e o ArcMAP pertencente ao conjunto ArcGIS. O método da trincheira evidenciou que o capim Paspalum possui grande volume de raízes tanto nos primeiros $0,40 \mathrm{~m}$ até a $1,30 \mathrm{~m}$ de profundidade do perfil do solo. Foi possível observar que o comprimento e o volume radicular do capim Paspalum alcançam profundidades além de 1,70 $\mathrm{m}$ de profundidade, importante para aumento da resistência do solo aos processos erosivos. O método da trincheira quando comparado com o método do anel volumétrico se mostrou mais eficiente para a compreensão do comportamento do sistema radicular do capim paspalum uma vez que permite uma avaliação da sua distribuição espacial com melhor detalhamento.

Palavras-chave: Volume radicular. Bioengenharia de solos. Software Safira.

\footnotetext{
${ }^{*}$ Corresponding author

${ }^{1}$ Received for publication in $05 / 16 / 2019$; accepted in $01 / 13 / 2020$.

Paper extracted from the research project developed by Laboratório de Erosão e Sedimentação do Solo LABES.

${ }^{2}$ Undergraduate Agronomic Engineering, Universidade Federal de Sergipe, São Cristóvão, SE, Brazil; airtonsocial@hotmail.com - ORCID: 0000-0002-2180-6228, guilhermematos.antonio@gmail.com - ORCID: 0000-0002-4585-6860.

${ }^{3}$ Graduate Program in Intellectual Property Science, Universidade Federal de Sergipe, São Cristóvão, SE, Brazil; vidal.center@academico.ufs.br - ORCID: 0000-0001-8659-8557

${ }^{4}$ Graduate Program in Agriculture and Biodiversity, Universidade Federal de Sergipe, São Cristóvão, SE, Brazil; fholanda@infonet.com.br - ORCID: 0000-0001-6812-6679.

${ }^{5}$ Department of Agronomic Engineering, Universidade Federal de Sergipe, São Cristóvão, SE, Brazil; alceupedrotti@gmail.com - ORCID: 0000-0003-3086-8399.
} 


\section{INTRODUCTION}

Erosion is responsible for the detachment and drag of soil particles, by the actions of water and wind, occurring more rapidly due to anthropic actions (BISPO et al., 2017; ISMAEL et al., 2013; STONE et al., 2015). Besides natural factors, anthropic actions such as the removal of the riparian forest for cultivation and the consequent silting up of the riverbed promote and intensify the processes of riverbank erosion (STAVI; GUSAROV; HALBACCOTOARA-ZAMFIR, 2019).

Studies conducted by Holanda, Rocha and Oliveira (2008), Araujo Filho et al. (2013) and Machado et al. (2015) show that there are several techniques to control erosion on river banks or slopes, such as the use of rockfills or gabion, which can have good results, but are quite expensive. Biotechnologies are demanded, such as soil bioengineering using living materials, such as seedlings, cuttings of native species that contribute to the improvement of soil resistance, in addition to floristic recovery.

In order to understand the role of some species to contain landslides, the grass vetiver (Chrysopogon zizanioides (L.) Nash), is presented as the most used species worldwide (PUNAMIYA et al., 2010; PIDATALA et al., 2016). However, vetiver grass is an exotic species in Brazil and, according to CONAMA Resolution no. 429, of 2011, is not recommended for recovery of PPAs (Permanent Preservation Areas) such as river banks. Peres, Ralisch and Ripol (2009) highlight that, besides not being recommended by law, exotic species promote losses due to competition with native species, still remaining in the eroded sites, thus making it difficult to maintain the environmental balance of the PPAs.

Paspalum grass is a perennial native species in Brazil, but occurring throughout the Americas (MORRONE; DENHAM; ZULOAGA, 2004; REIS et al., 2015), also belonging to the Poaceae family, and found in woodland and roadsides.

In studies analyzing the biotechnical potential of Paspalum grass submitted to different simple superphosphate doses and moisture contents, it was noted that in $60 \%$ of Total Pore Volume (TPV) of soils occupied with water, the plant showed the best tillering results, with good formation of aerial and root biomass, important for the protection of slopes against soil erosion and soil reinforcement by roots (HOLANDA et al., 2010).

The most important advances in the studies of soil bioengineering technologies are in the adoption of more efficient techniques, mainly to avoid landslides and soil mass movements (LEÃO; SOUZA, 2018). Thus, methodologies that evaluate root development in the soil profile using less destructive methods, decreasing the damage to the plant, decreases the probability of data interference by displacement of samples and or reworking as a result of withdrawal. Such knowledge can be achieved through the use of Digital Image Processing techniques, from data capture via photomechanical image processing (PEGOLO; CASONATO, 2014), use of sensors that analyze production capacity (SANA et al., 2014), or even optical phenomena resulting from controlled frequencies (O'CALLAGHAN et al., 2018). One of the techniques that can achieve this goal is the use of geoprocessing (SOUZA; SILVA, 2016), together with reference data. The use of information systems of points and polygons has been introduced as a new method to survey erodibility data map (BATISTA, 2015) through modeling. From numerical data and models together with data from the root system it is possible to understand the behavior and interaction between the systems (soil x plant).

The use of digital image processing has become popular in agriculture, from the quantification of probiotic bacteria performance (SANA et al., 2014) to soil disturbance analysis by agricultural equipment (LI et al., 2019), as well as in the evaluation of root systems (CARDUCCI et al., 2014). The analysis is based on distance transformation, a very useful process to understand length patterns, and adapted methods of data of volume and area of an object, such as the perimeter and architecture of roots (GONÇALVES; MITISHITA, 2016; PLOTZE; BRUNO 2004), for root system analysis.

Currently, studies of root systems use several classical methods, sometimes exhaustive and very exposed to measurement errors, or through invasive and destructive techniques, thus becoming subjective, expensive and boring, generating the urgency of automation of this process. Studying a software for digital image processing aiming at the study of roots, Jorge and Crestana (1996) presented SIARCS ${ }^{\circledR}$ (Integrated System for root analysis and soil cover), which was later replaced by SAFIRA $\AA$ because the first one had limitations of analysis, such as morphological tools (JORGE; RODRIGUES, 2008). Thus, the Fiber and Roots Analysis System (SAFIRA $\left.{ }^{\circledR}\right)$ was created to show the measurements of the surface area, volume and length of fibers and roots using the transformed distance (JORGE; SILVA, 2010).

The objective of this work was to evaluate the growth and distribution characteristics of the root system of Paspalum millegrana Schrad. grass in Entisol using Digital Imaging Processing (DIP).

\section{MATERIALS AND METHODS}

\section{Characterization of the study area}

To collect data of Paspalum grass roots, a pit ( $1 \mathrm{~m}$ wide, $5 \mathrm{~m}$ long and $2 \mathrm{~m}$ deep) was initially 
opened in soil classified as Entisol, in an experimental area of the Universidade Federal de Sergipe (UFS), where individuals of Paspalum and Vetiver grass have been cultivated for 2.5 years. In this experimental area, plant analyses were performed using soil profile wall method (VASCONCELOS et al., 2003) and volumetric ring method.

\section{Collection of root data}

After the pit was opened, its frontal face, where the plant and its root system were located, was scarified to be photographed and later subjected to root collection. The profile wall method was performed in the pit previously opened with dimensions of $1.0 \times 1.0 \mathrm{~m}$, initially photographed in a first stage. The area immediately below $0.70 \mathrm{~m} \mathrm{x}$ $0.70 \mathrm{~m}$ was not photographed because of recurrent elevation of the water table, where the very sandy soil was not stable enough, causing constant collapse. Using a water pump, the slope was submitted to a jet which allows the cleaning of the soil that covered the roots in the pit, promoting their integral exposure to be adequately photographed, enabling the collection of fair pictures in the soil profile, which showed the natural distribution of roots.

The roots were then sprayed with yellow paint to enhance their contrast with the soil behind, and thus gain more prominence in the images, which were used in the analysis with the SAFIRA software. Another scarification was performed to remove the excess of ink that also covered the soil. Then, an additional water jet and a steel spatula were used to leave only the roots highlighted in yellow color (Figures 1a and 1b).
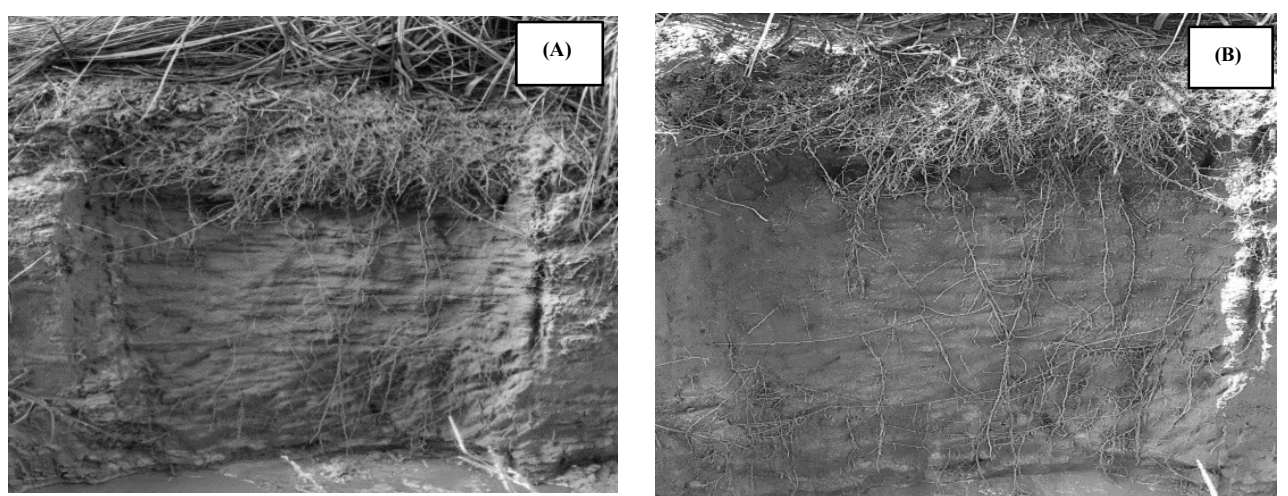

Figure 1. A. Frontal face of the profile wall after application of the yellow ink spray B. Pit after the removal of ink excess, showing the exposure of the root system.

The images were collected by a $4608 \times 2592$ pixel resolution digital camera capturing 32 frames per second at a distance of approximately $1 \mathrm{~m}$ apart and organized into $0.1 \times 0.1 \mathrm{~m}$ squares delineated by means of a wooden grid composed of 100 squares with a dimension of $1.0 \times 1.0 \mathrm{~m}$, adapting the methodology described by Teixeira et al. (2017). At each image and root collection with the wooden grid in the profile, 50 images were recorded using the camera and then scanned on a flatbed scanner with spatial resolution of $512 \times 512$ pixels and 256 shades of gray per pixel, analyzed by SAFIRA Software, resulting in coordinates that were georeferenced using ArcGis.

After recording the images, the soil samples were collected with a volumetric ring with approximately $50 \mathrm{~mm}^{3}$ volume. This methodology is used to collect soil samples with undisturbed structure from these rings of known internal volume (TEIXEIRA et al., 2017).

Once the soil was collected, the samples (soil + root) were packed and properly identified in plastic bags and placed in a dry room. After drying, the roots were individualized using tweezers and placed in paper bags with sample identifications. The roots were then washed on a sieve using running water and then placed in the forced circulation oven drying for 24 hours at $60{ }^{\circ} \mathrm{C}$. This procedure was adapted from the methodology proposed by Fante Junior et al. (1999).

\section{Digital image processing}

The images resulted from the photographic records and the root collection with the volumetric ring, which were scanned on a flatbed scanner and then processed by the SAFIRA software, which provided data of volume, surface area and length in root diameters. The Fiber and Roots Analysis System (SAFIRA), which was originally the SIARCS ${ }^{\circledR}$ Software (Integrated System for Roots and Soil Cover Analysis), has its analysis limitations, mostly related to morphological tools (JORGE; RODRIGUES, 2008).

The development of Heatmaps, the kriging interpolation and smoothing methods by the Splaine method were used. 


\section{Experimental design}

Initially, the Anderson-Darling statistical test was applied, which identified if each set of measures was normally distributed, taking into consideration the significance level of $0.05(5 \%)$. The R-statistic System (R CORE TEAM, 2019) was used for the data regarding root length and diameter, considering the weighted mean of each quadrant. The nonparametric correlation equation of Spearman's ranks was used for the measurements of the Correlation Coefficient. For analysis of the error samples, the ttest with a $p$-value of 0.05 (5\% significance) was used. The Spline method, described by Yamamoto and Landim (2015) was used to elaborate the heatmaps of the Paspalum grass root system using data collected by SAFIRA. This interpolation method suggests values employing a mathematical function, which minimizes surface curvature, resulting in a smooth surface that passes exactly through the sampled points.

\section{RESULTS AND DISCUSSION}

Based on the results of the volume of roots using the methods of profile wall and volumetric ring, different values of volume were observed when analyzed through the digital image processing and at different soil depths. A maximum root volume value of $47.79 \mathrm{~mm}^{3}$ was identified for the initial soil squares (A, B, C, and D), in the topsoil at a depth of 0 to $40 \mathrm{~cm}$ (Figures $2 \mathrm{a}$, and $2 \mathrm{~b}$ ).

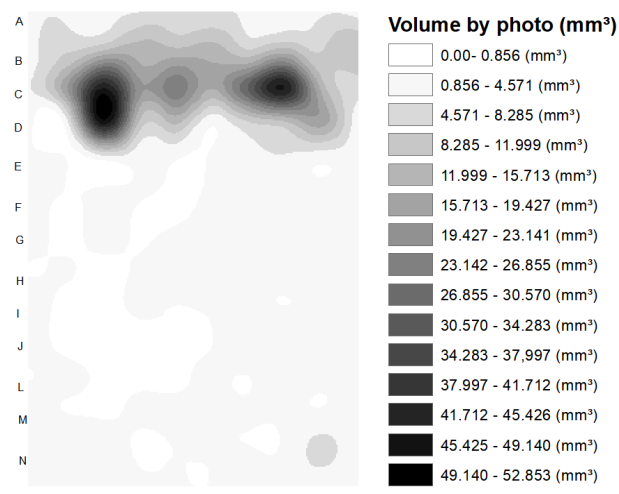

(A)

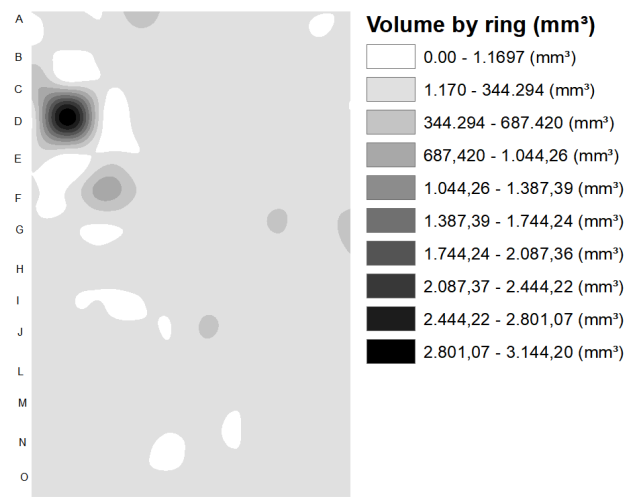

(B)

Figure 2. A. Heatmap of the volume by profile wall method $\left(\mathrm{mm}^{3}\right)$ and B. Heatmap of the root volume according to the volumetric ring method $\left(\mathrm{mm}^{3}\right)$. Axes containing letters and numbers describe the analyzed squares.

According to the interpolation method, the Spline smoothing equation was used, which can be expressed by the number of nodes (points where the segments connect), the order and degree of the polynomial as described by Silva et al. (2019), being more flexible than the Fourier equation, used here to smooth the edges after interpolation of the obtained data during processing. It was possible to reconstruct heatmap descriptions of the root system of Paspalum grass. Such maps displayed darker shades for the representation of the spots with the highest concentration of root volume and in each soil layer. The highlighted root volumes of the squares were C3 $\left(43.14 \mathrm{~mm}^{3}\right)$ and $\mathrm{C} 8\left(44.89 \mathrm{~mm}^{3}\right)$ in the layer up to $0.3 \mathrm{~m}$ and D3 $\left(47.74 \mathrm{~mm}^{3}\right)$ at $0.4 \mathrm{~m}$ depth of soil profile, values close to those described by Stumpf et al. (2016) at a depth of $0.10 \mathrm{~m}$, studying the species Urochloa brizantha (Poaceae), demonstrating a proximity to the data analyzed by other validated methods.

As the measurements showed the nonparametric behavior for all studied variables as mentioned by Myers and Sirois (2006) guide, the correlation analysis of Spearman' ranks for nonparametric data was needed. It was observed that the profile wall method and the volumetric ring method exhibited distinct heatmaps when the data of volume, length and surface area of the roots were analyzed in the deeper layers of the soil profile. A higher density of root system is necessary for the efficient absorption of water and nutrients in the developing plant. The use of grasses in soil bioengineering techniques is of great value since its purpose is the fixation and stability of the soil on slopes and riverbanks. The Poaceae family mostly has complex, fibrous root system, composed of different types of roots formed during the different phases of development, with the capacity for mycorrhizal association, important for the increase in its volume of nutrient absorption (SANTOS et al., 2018).

By evaluating the data of the volumetric ring method, is possible to state that it has as a limiting factor for the evaluation of roots in rings with circumference of only $50 \mathrm{~mm}^{3}$, despite the external area of the square $\left(0.10 \mathrm{~m}^{2}\right)$, a limitation not present in the profile wall method, which captured images in the entire square area.

Analyzing the correlation of existing positions between the variables Root Volume by the Ring method (VRA) and Root Area by the Ring method (Table 1), we can observe high values with 
statistical significance in their behavior (VRA X VRA $\mathrm{r}=0.99 ; \mathrm{p}<0.05)$, and similar behavior in the variables Root Area and Root Volume by the profile wall method (ART X VRT, $r=0.92 ; \mathrm{p}<0.05$ ).

Table 1. Spearman's rank correlation coefficient and significance level between variables, RAR, RVR, RDR, RLR, RAP, RVP and RDP.

\begin{tabular}{lccccccccc}
\hline & & RAR & RDR & RLR & RVR & RAP & DRT & RLP & RVP \\
\hline RAR & r & & & & & & & & \\
RDR & $\mathrm{r}$ & $0.80 \mathrm{~ns}$ & & & & & & & \\
RLR & $\mathrm{r}$ & $0.97 \mathrm{~ns}$ & $0.81 \mathrm{~ns}$ & & & & & & \\
RVR & $\mathrm{r}$ & $0.99 \mathrm{~ns}$ & $0.86 \mathrm{~ns}$ & $0.96 \mathrm{~ns}$ & & & & & \\
RAP & $\mathrm{r}$ & $0.07^{*}$ & $0.07^{*}$ & $0.09^{*}$ & $0.07^{*}$ & & & & \\
RDP & $\mathrm{r}$ & $0.19^{*}$ & $0.22^{*}$ & $0.21^{*}$ & $0.20^{*}$ & $0.39 \mathrm{~ns}$ & & & \\
RLP & $\mathrm{r}$ & $0.10^{*}$ & $0.11^{*}$ & $0.14^{*}$ & $0.10^{*}$ & $0.83 \mathrm{~ns}$ & $0.30 \mathrm{~ns}$ & & \\
RVP & $\mathrm{r}$ & $0.12^{*}$ & $0.13^{*}$ & $0.14^{*}$ & $0.12^{*}$ & $0.92 \mathrm{~ns}$ & $0.64 \mathrm{~ns}$ & $0.79 \mathrm{~ns}$ & \\
\hline
\end{tabular}

ARA- Root Area by the volumetric ring method, RVR- Root Volume by the volumetric ring method, RDR - Root Diameter by the volumetric ring method, RLR - Root Length by the volumetric ring method, RAP- Roots Area by the profile wall method, RVP - Volume of Roots by the profile wall method, RDP - Root Diameter by the profile wall method, RLP - Root Length by the profile wall method.

$\mathrm{r}=$ Correlation coefficient.

* Significant at $5 \%$ probability of error, $t$ test.

${ }^{n s}$ Not significant at $5 \%$ probability of error, $t$ test.

The evaluation of the root volume results by the profile wall method allowed us to identify the location of the squares with the highest concentration, length and surface area of the roots in the superficial layers of the soil (Figures $3 a$ and $3 b$ ). The mentioned data agreed with Stumpf et al.
(2016), who carried out a study on the development and influence of Urochloa brizantha root system in a degraded soil, recording root growth up to $0.30 \mathrm{~m}$ and greater root volume and length in the layer of $0.10-0.20 \mathrm{~m}$.

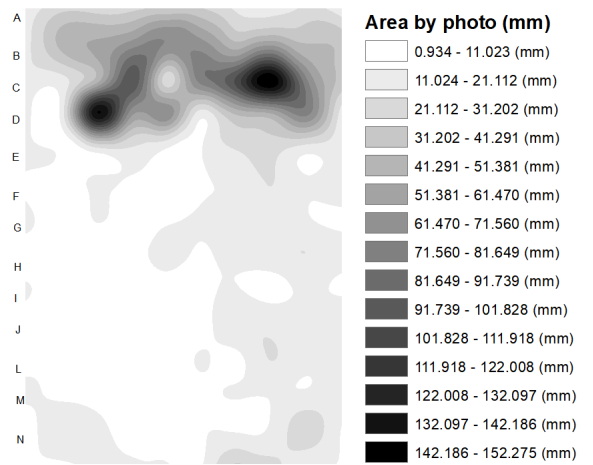

(A)

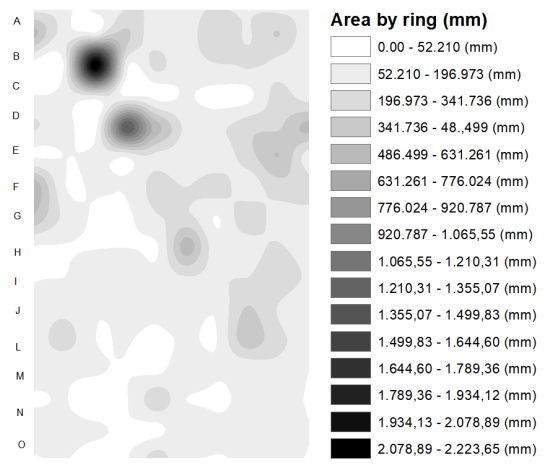

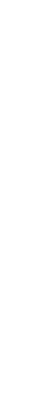

Figure 3. A. Heatmap of the area present in the root system of Paspalum grass using the profile wall method and B. Heatmap of the area present in the root system of Paspalum grass using the volumetric ring method. Axes containing letters and numbers describe the analyzed squares.

The data of root length obtained from the profile wall method allowed us to identify that they showed a homogeneous distribution in most of the analyzed squares, reaching a depth of $1.40 \mathrm{~m}$, with emphasis on the squares B5 $(5.39834 \mathrm{~mm})$ at $0.20 \mathrm{~m}$ depth, C3 (5.39344 mm), C4 (5.77825 mm), and C8 $(5.67554 \mathrm{~mm})$ at $0.30 \mathrm{~m}$ depth (Figure $4 \mathrm{a})$.

Also regarding the data for the volumetric ring method, the highlight was the square D2 $(139.118 \mathrm{~mm})$ at $0.40 \mathrm{~m}$ depth. The variable Root volume is of great importance when using plant species in the stability of soils on slopes, due to the physical-mechanical contribution in increasing soil cohesion (GÓMEZ; GARCIA; ROMANEL, 2017), demonstrating the need to use species that positively respond by increasing root density at either low or high plant density (DIÓGENES et al., 2016).

By comparing the heatmap of the length of the Paspalum grass root system using the profile wall method (Figure 4a) and the heatmap of the length of the root system using the volumetric ring method (Figure 4b), it was noticed a concentration of roots more present in the first $0.50 \mathrm{~m}$ of soil (topsoil). It is also possible to notice the presence of darker spots that represent a high concentration of roots in much of the analyzed soil profile, with emphasis on the M9 square $(5.56300 \mathrm{~mm})$ at $1.70 \mathrm{~m}$ depth.

Rev. Caatinga, Mossoró, v. 33, n. 1, p. 100 - 107, jan. - mar., 2020 


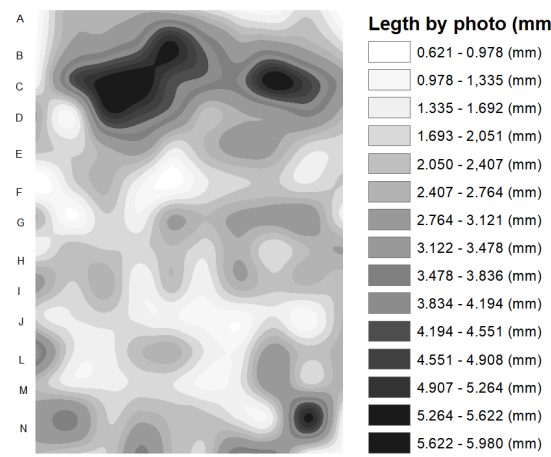

(A)

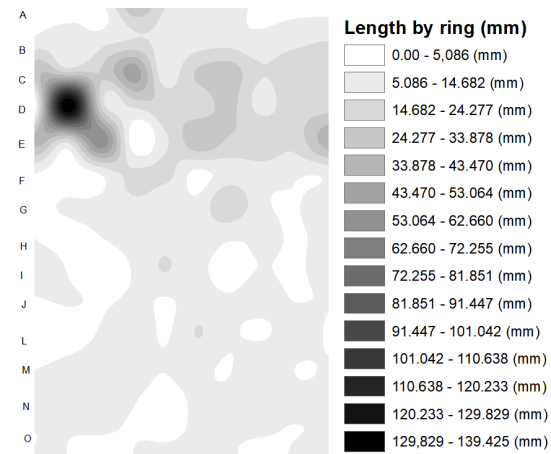

Figure 4. A. Heatmap of the length present in the Paspalum root system using the profile wall method and B. Heatmap of the length present in the Paspalum root system using the volumetric ring method. Axes containing letters and numbers describe the squares analyzed.

The behavior of the values referring to the average root length of Paspalum grass agreed with those identified by Machado et al. (2015), who worked with vetiver grass (Chrysopogon zizanioides (L.) Roberty) and found higher root volume values in the initial layers of 0.50 meters in length.

The capacity for deep rooting is important because it indicates the quality of the root system and its capacity to support the plant, as well as a good vegetative development (TOMLINSON, 1990; BARROS et al., 1996; AQUINO et al., 2015). Santana (2012) reports that root length analyses in the profile showed good results for maize (Zea mays L.) when obtained through digital image processing using also SAFIRA software.

For the specific activity of slope recomposition it is valuable to select plant species that have important characteristics to develop in bare soil (HOLANDA et al., 2010). According to Pereira (2006), such characteristics can be drought tolerance, development of a deep root system, good vigor in growth, ease of propagation, good seed production, good resistance in regions of low fertility and good soil cover promoted by the aerial part.

In soil bioengineering, the use of species with good rooting capacity in deeper soil layers is of great importance, as erosion on slopes, whether on riverbanks or slopes, is aggravated due to differences in morphological characteristics, such as root volume or length of the used species (HOLANDA et al., 2009). A positive behavior was exhibited by Paspalum grass, allowing the most efficient fulfillment of its function, proved by the data presented through the studied root analysis methodologies.

\section{CONCLUSIONS}

The root length obtained by the profile wall method indicates the presence of long roots up to the deepest layers of the soil profile, exceeding $1.70 \mathrm{~m}$.

The largest area of the roots was most evident at a depth of $0.40 \mathrm{~m}$, showing the highest concentration in the most superficial layers

The results obtained by the profile wall Method emphasize the presence of longer roots in the lower layers of the soil (greater depths).

The profile wall method when compared to the volumetric ring method proved to be more efficient for understanding the behavior of the Paspalum grass root system since it allows an evaluation of its spatial distribution with better detail.

The processing of SAFIRA software to evaluate the root system of Paspalum grass proved to be very efficient to better understand the length, area and volume of roots of this species in the soil profile, allowing the observation of a predominantly significant correlation between the studied variables.

The roots of Paspalum grass showed length, density and distribution in the soil, which are very important as biotechnical characteristics to be adopted in soil bioengineering works in order to control erosion on slopes and riverbanks.

\section{REFERENCES}

ARAUJO FILHO, R. N. de et al. Técnica de bioengenharia de solos no controle da erosão no baixo São Francisco sergipano. Magistra, 25: 242250,2013

AQUINO, G. S. et al. Sistema radicular e produtividade de soqueiras de cana-de-açúcar sob diferentes quantidades de palhada. Pesquisa Agropecuária Brasileira, 50: 1150-1159, 2015.

BARROS, J. C. S. M. et al. Avaliação da capacidade de enraizamento e desenvolvimento vegetativo de genótipos de videira para porta-enxerto. Scientia Agrícola, 53: 285-292, 1996.

BATISTA, C. Avaliação do cálculo de erosividade em escala regional com o auxílio de geoprocessamento na Serra de Baturité - CE. Revista de Geociências do Nordeste, 1: 22-36, 2015. 
BISPO, D. F. A. et al. Soil, water, nutrients and soil organic matter losses by water erosion as a function of soil management in the Posses sub-watershed, Extrema, Minas Gerais, Brazil. Semina: Ciências Agrárias, 38: 1813-1824, 2017.

CARDUCCI, C. E. et al. Spatial distribution of coffee roots and pores of two Latosols under conservationist management. Revista Brasileira de Engenharia Agrícola e Ambiental, 18: 270-278, 2014.

DIÓGENES, L. C. et al. Resistência à penetração e atributos químicos em um latossolo do Piauí sob monocultivos e consórcio de gramíneas irrigados. IRRIGA, 1: 181-195, 2016.

FANTE JÚNIOR., L. et al. Distribuição do sistema radicular de uma cultura de aveia forrageira. Scientia Agrícola, 56: 1091-1100, 1999.

GÓMEZ, J.; GARCIA, D. M.; ROMANEL, C. Análise numérica 3D da estabilidade de taludes de grande altura em minas a céu aberto. Revista Interdisciplinar De Pesquisa Em Engenharia, 2: 1 $-15,2017$.

GONÇALVES, G. A.; MITISHITA, E. A. O Uso da Distância de Hausdorff como Medida de Similaridade em Sistemas Automáticos de Atualização Cartográfica. Boletim de Ciências Geodésicas, 22: 719-735, 2016.

HOLANDA, F. S. R. et al. Controle da erosão em margens de cursos d'água: das soluções empíricas à técnica da bioengenharia de solos. Ra'ega O Espaço Geográfico em Análise, 17: 93-101, 2009.

HOLANDA, F. S. R. et al. Crescimento inicial de espécies florestais na recomposição da mata ciliar em taludes submetidos à técnica da bioengenharia de solos. Ciencia Florestal, 20: 157-167, 2010.

HOLANDA, F. S. R.; ROCHA, I. P.; OLIVEIRA, V. $\mathrm{S}$. Estabilização de taludes marginais com técnicas de bioengenharia de solos no Baixo São Francisco. Revista Brasileira de Engenharia Agrícola e Ambiental, 12: 570-575, 2008.

ISMAEL, F. C. M. et al. Diagnóstico da erosão do solo na área do Campus da UFCG em Pombal - PB. Revista Verde, 8: 77-86, 2013.

JORGE, L. A. C.; CRESTANA, S. SIARCS 3.0: novo aplicativo para análise de imagens digitais aplicado a Ciência do Solo. CONGRESSO LATINO AMERICANO DE CIÊNCIA DO SOLO, 1., 1996, Águas de Lindoia. Anais... Águas de Lindoia: SBCS, 1996. p. 1-5.
JORGE, L. C.; RODRIGUES, A. O. Safira: sistema de análise de fibras e raízes. Embrapa Instrumentação-Boletim de Pesquisa e Desenvolvimento (INFOTECA-E), 2008.

JORGE, L. C.; SILVA, D. C. Safira: Manual de utilização. Embrapa Instrumentação-Livro científico (ALICE), 2010.

LEÃO, J. C.; SOUZA, P. H. Sistema inteligente de monitoramento de deslizamento de solos. Revista Gestão \& Sustentabilidade Ambiental, 7: 508-524, 2018 .

LI, P. et al. A new method to analyse the soil movement during tillage operations using a novel digital image processing algorithm. Computers and Electronics in Agriculture, 156: 43-50, 2019.

MACHADO, L. et al. Contribuição do sistema radicular do capim-vetiver para estabilização do talude do Rio São Francisco. Semina: Ciências Agrárias, 36: 2453-2464, 2015.

MORRONE, O.; DENHAM, S. S.; ZULOAGA, F. O. Revisión Taxonómica del Género Paspalum Grupo Eriantha (Poaceae, Panicoideae, Paniceae). Annals of the Missouri Botanical Garden, 91: 225 $-246,2004$.

MYERS, L.; SIROIS, M. J. Spearman Correlation Coefficients, Differences between. In: Encyclopedia of Statistical Sciences. Atlanta, Geórgia, EUA: American Cancer Society, v. 1p. 1-2, 2006.

O'CALLAGHAN, F. E. et al. New live screening of plant-nematode interactions in the rhizosphere. Scientific Reports, 8: 1-17, 2018.

PEGOLO, F.; CASONATO, O. Studio sull'affidabilità interesaminatore della valutazione osservazionale delle discinesie scapolari. Scienza Riabilitativa, 16: 24-29, 2014.

PEREIRA, A. R. Como selecionar plantas para áreas degradadas e controle de erosão. Belo Horizonte, MG: Fapi, p. 70-72, 2006.

PERES, M. C. A. P.; RALISCH, R.; RIPOL, C. V. Avaliação do programa estadual "Mata Ciliar" no município de Pitangueiras, Paraná. Semina: Ciências Agrárias, 30: 563-574, 2009.

PIDATALA, V. R. et al. Identification of Biochemical Pathways Associated with Lead Tolerance and Detoxification in Chrysopogon zizanioides L. Nash (Vetiver) by Metabolic Profiling. Environmental Science \& Technology, 50: 2530-2537, 2016. 
PLOTZE, R. O.; BRUNO, O. M. Estudo e comparação de algoritmos de esqueletonização para imagens binárias. In: CONGRESSO BRASILEIRO DE COMPUTAÇÃO-CBCOMP, 4., 2004, Vale do Itajaí. Anais... Vale do Itajaí: UNIVALI: 2004. p. 59 -64 .

PUNAMIYA, P. et al. Symbiotic role of Glomus mosseae in phytoextraction of lead in vetiver grass [Chrysopogon zizanioides (L.)]. Journal of Hazardous Materials, 177: 465-474, 2010.

R DEVELOPMENT CORE TEAM. R: A Language and Environment for Statistical Computing. Vienna, Austria: 2019.

REIS, P. A. et al. Paspalum minutispiculatum (Poaceae, Panicoideae): A new annual species from Central Brazil. Systematic botany, 40: 746-754, 2015.

SANA, R. S. et al. Variabilidade espacial de atributos físico-químicos do solo e seus efeitos na produtividade do algodoeiro. Revista Brasileira de Engenharia Agrícola e Ambiental, 18: 994-1002, 2014.

SANTANA, C. T. C. Comportamento de milho (Zea Mays L.) e propriedades físicas do solo, no sistema plantio direto, em resposta a aplicação de fertilizante organomineral. 2012. 49f. Dissertação (Mestrado em Agronomia: Área de Concentração em Agricultura) - Universidade Estadual Paulista, Faculdade de Ciências Agronômicas, Botucatu, 2012.

SANTOS, J. S. et al. Fungos micorrízicos arbusculares e endofítios "Dark Septate" no desenvolvimento da biomassa do capim vetiver. Revista Caatinga, 31: 602-611, 2018.

SILVA, M. C. et al. Estudo de simulação na análise de dados funcionais: Spline x Fourier. Sigmae, 8: 214-220, 2019.

SOUZA, A. C. C.; SILVA, M. L. Geoprocessamento Aplicado ao Levantamento de Solos no Município de Inconfidentes-MG (GIS Applied to the Soil Survey in the City of Inconfidentes-MG). Revista Brasileira de Geografia Física, 9: 200-214, 2016.

STAVI, I.; GUSAROV, Y.; HALBAC-COTOARAZAMFIR, R. Collapse and failure of ancient agricultural stone terraces: On-site geomorphic processes, pedogenic mechanisms, and soil quality. Geoderma, 344: 144-152, 2019.

STONE, L. F. et al. Qualidade física de um Latossolo Vermelho ácrico sob sistemas silviagrícolas. Revista Brasileira de Engenharia Agrícola e Ambiental, 19: 953-960, 2015.

STUMPF, L. et al. Condição física e desenvolvimento radicular de gramíneas em solo construído após mineração de carvão. Pesquisa Agropecuária Brasileira, 51: 1078-1087, 2016.

TEIXEIRA, P. C. et al. Manual de Métodos de Análise de Solo. 3. ed. Brasília-DF: Embrapa Solos, 2017.

TOMLINSON, P. B. The structural biology of palms. Harvard University, Harvard Forest, Petersham, Massachusetts, USA.: CABI, 1990.

VASCONCELOS, A. C. M. et al. Avaliação do sistema radicular da cana-de-açúcar por diferentes métodos. Revista Brasileira de Ciência do Solo, 27: 849-858, 2003.

YAMAMOTO, J. K.; LANDIM, P. M. B. Geoestatística: conceitos e aplicações. São Paulo, SP: Oficina de Textos, 2015. 216 p. 